\title{
PEMEBELAJARAN SENTRA DALAM MEMBANGUN KECERDASAN JAMAK DI SEKOLAH DASAR
}

\author{
Maharani Ramadhanti ${ }^{1}$, M. Syarif Sumantri ${ }^{2}$, Edwita $^{3}$ \\ Universitas Negeri Jakarta ${ }^{1,2,3}$ \\ maharaniramadhanti@gmail.com ${ }^{1}$
}

\begin{abstract}
ABSTRAK
Penelitian ini bertujuan untuk menemukan kecerdasan jamak dalam pembelajaran Sentra di sekolah dasar. Penelitian ini dilakukan di MI Plus kota Tangerang AsySyukriyyah dengan 14 siswa dari kelas 1 B sebagai subjek penelitian. Alasan untuk subjek yang dipilih adalah karena kelas yang unik dan memerlukan penanganan khusus. Penelitian ini menggunakan metode kualitatif dan untuk metode penelitiannya mengikuti aliran penelitian secara bertahap progresif dari Spradley. Proses pengumpulan data menggunakan observasi, wawancara, dan analisis dokumen, sedangkan analisis data terdiri dari: analisis domain, analisis taksonomi, dan tema analisis. Hasil dari penelitian menunjukkan bahwa kecerdasan jamak yang di bangun dalam pembelajaran sentradi MI Plus AsySyukriyyah, antara lain: kecerdasan linguistik, logika-matematic, spasial, interpersonal, intrapersonal, kinestetik, dan naturalis. Simpulan bahwa pembelajaran sentra di MI Plus Asy-Syukriyyah membangun delapan kecerdasan jamak, kecerdasan yang dibangun antara lain kecerdasan: interpersonal, naturalis, intrapersonal, spasial, kinestetik, musical, linguistik dan logis matematik.
\end{abstract}

Kata Kunci: Pembelajaran Sentra, Kecerdasan Jamak, Sekolah Dasar.

\begin{abstract}
This study aims to find multiple intelligences in learning centers in primary schools. This research was conducted in MI Plus Tangerang city Asy-Syukriyyah with 14 students from class $1 \mathrm{~B}$ as research subjects. The reason for the chosen subject is because the class is unique and needed special holding. This study uses qualitative methods and for the research methods to follow the research flow for the advancement of Spradley. The process of collecting data uses observation, interviews, and document analysis, while data analysis consists of: domain analysis, taxonomic analysis, and analytical themes. The results showed that the multiple intelligences obtained in the learning of MI Plus Asy-Syukriyyah center include: linguistic intelligence, logic-mathematical, spatial, interpersonal, intrapersonal, kinesthetic, and naturalist. Conclusion is learning center in MI Plus Asy-Syukriyyah building multiple intelligences intelligence, intelligence built between intelligence: interpersonal, naturalist, intrapersonal, spatial, kinesthetic, music, linguistic and logical mathematical.
\end{abstract}

Keywords: BCCT Learning, Multiple Intelligences, Elementary School 


\section{PENDAHULUAN}

Setiap sekolah mempunyai ciri khas pembelajaran masing-masing. Pembelajaran menjadi tolak ukur keberhasilan dalam mendidik anak.Para pendidik mulai berinovasi mencari pembelajaran yang sesuai dengan perkembangan peserta didik.Pembelajaran diharapkan tidak hanya sekedar pemberian informasi kepada anak.Namun juga berisi nilai-nilai pendidikan yang dapat mengakumulasi kecerdasan setiap anak.

Dalam memilih pembelajaran yang tepat para pendidik harus paham mengenai kebutuhan anak yaitu dengan cara mengetahui karakteristik peserta didik. Menurut Jamaris (2010) karakteristik siswa sekolah dasar yang dikelompokan dalam tahapan perkembangan siswa sekolah dasar. (1) Perkembangan Fisik, Pada usia 6 tahun kepala manusia berukuran sepertujuh dari ukuran tubuhnya. Pada usia 6 tahun anak telah memiliki proposi tubuh yang akan mewarnai proposi tubuhnya dimasa dewasa. Secara normal pertambahan berat badan secara normal hanya 2, 5 inchi pertahun dan pertambahan berat badan secara normal hanya 2,5-3,5 kilogram pertahun. (2) Perkembangan Otak, Perkembangan kecerdasan anak usia 4 tahun mencapai 50\%, usia 8 tahun mencapai $80 \%$, usia 12 tahun kecerdasan anak berkembang sebanyak $90 \%$ dan pada usia 18 tahun perkembangan kecerdasan mencapai perkembangan yang optimal. (3) Perkembangan kognitif siswa sekolah dasar, Fase operasional kongkret merupakan fase ketiga dalam perkembangan kognitif anak. Dengan mengetahui tahap perkembangan anak usia sekolah dasar diharapkan pendidikan dapat menyiapkan segala kebutuhan siswa sesuai dengan apa yang dibutuhkan. Dan menyadari bahwa siswa sekolah dasar senang bermain, senang bergerak, senang bekerja dalam kelompok, dan senang bereksperimen. Dengan begitu proses pembelajaran menjadi menyenangkan.

Dunia anak adalah dunia bermain, informasi dan pendidikan dapat mudah di berikan jika pembelajaran yang digunakan sesuai dengan apa yang perkembangan anak. Sekolah MI Plus menggunakan pembelajaran Sentra dalam proses pembelajaran. Pembelajaran ini memperkenalkan pembelajaran dengan konsep bermain sambil belajar.Pembelajaran ini dinilai cocok digunakan untuk anak-anak sekolah dasar.

Pembelajaran Sentra dicetuskan oleh Maria Montessori yang kemudian diinovasi dan dikembangkan di Florida, USA. Di Indonesia model ini diterjemahkan menjadi "Model Sentra dan Saat Lingkaran". Peserta didik diajarkan sebagai "subjek otonom" yang secara bebas mengembangkan kemampuannya secara maksimal.Tugas pendidik hanya sebatas memfasilitasi, memotivasi, mendampingi, dan memberi pijakan.

Menurut Dyah (2012) mengatakan model pembelajaran sentra adalah suatu model pembelajaran dengan strategi belajar sambil bermain yang berfokus pada anak dalam proses pembelajaran berpusat di sentra main dalam lingkaran dengan menggunakan 4 jenis pijakan (pijakan lingkungan main, pijakan sebelum 
main, pijakan selama main, pijakan setelah main). Menurut Power (2005) menjelaskan mengenai pembelajaran sentra yaitu pembelajaran yang terfokus pada subjek tertentu untuk dijadikan sebuah tema pembelajaran.Artinya penyusunan proses pembelajaran disusun berdasarkan hasil observasi mengenai perkembangan dan kebutuhan anak, setelah mengetahui hal tersebut, para pendidik membuat program-program menarik yang dapat memenuhi kebutuhan anak.

Sedangkan Depdiknas (2006) menambahkan pembelajaran sentra mendasarkan pada asumsi bahwa anak belajar melalui bermain dengan bendabenda dan orang-orang disekitarnya (lingkungan). Dalam bermain anak berinteraksi dengan lingkungannya.Pengalaman bermain yang tepat dapat mengoptimalkan seluruh aspek perkembangan anak, baik fisik, emosi, kognisi, maupun sosial anak.

Berbeda dengan penjelasan sebelumnya, menurut Mufrihatin (2008) pembelajaran sentra juga mengembangkan kecerdasan jamak, yang memandang bahwa setiap anak unik dan berbakat.Pendapat tersebut menerangkan bahwa sentra-sentra yang didesain khusus untuk mengembangkan kecerdasan jamak siswa, contoh untuk sentra drama siswa tidak hanya mengembangkan kecerdasan linguistik nya dalam berbicara tapi juga mengembangkan kecerdasan intrapersonal (kepercayaan diri), matematika-logis nya (drama tentang jual beli), dan spasial nya (membuat media rumah-rumahan ketika drama).

Pembelajaran Sentra yang diterapkan di MI Asy-Syukriyyah berbasis kecerdasan jamak. Setiap sentra didesain dengan memperhatikan kecerdasan masing-masing anak yang berbeda.Kecerdasan jamak yang dimiliki tiap anak diharapkan dapat dikembangkan dengan baik sehingga anak bisa tumbuh dengan percaya diri sesuai dengan minat dan bakatnya masing-masing. Setiap kecerdasan yang dimiliki diharapkan tidak hanya menunjang prestasinya namun juga dapat menunjang pembentukan pribadi anak menjadi manusia yang bermanfaat

Sedangkan Mustaqim (2004) menjelaskan kecerdasan seringkali dimaknai sebagai kemampuan memahami sesuatu dan kemampuan berpendapat.Dalam hal ini kecerdasan dipahami sebagai kemampuan intelektual yang menekankan logika dan memecahkan masalah.Kecerdasan biasa diukur dari kemampuan menjawab soal-soal tes standar diruang kelas (tes IQ). Tes tersebut menurut Hoerr (2007) sebenarnya hanya mengukur kecerdasan secara sempit karena hanya menekankan pada kecerdasan linguistik dan matematis-logis walaupun dapat mengukur keberhasilan anak di sekolah, namun tidak bisa memprediksi keberhasilan seseorang di dunia nyata, karena keberhasilan di dunia nyata saat ini mencakup lebih dari sekedar kecakapan linguistikdan matematis-logis.

Menurut Chatib (2013) mengatakan kecerdasan jamakadalah sebuah teori kecerdasan yang dimunculkan oleh Horward Gardner, seorang psikologi dari project zero Harvard University pada tahun 1983. Gardner dalam Hoerr (2007) menyediakan sarana untuk memetakan berbagai kemampuan yang dimiliki 
manusia, dengan mengelompokan kemampuan-kemampuan mereka ke dalam delapan kategori yang komprehensif atau "kecerdasan" berikut ini: kecerdasan linguistik, logis-matematis, spasial, musikal, kinestetik, intrapersonal, interpersonal, dan naturalis.Maka dari itu menarik untuk dilakukan penelitian mengenai pembelajaran sentra dalam membangun kecerdasan jamak di sekolah dasar.

\section{METODE PENELITIAN}

Penelitian ini menggunakan metode kualitatif yang mengacu kepada paradigma naturalistik alamiah yang bersumber pada pandangan fenomenologis khususnya yang berkaitan dengan teori yang di kembangkan (Spradley, 1980).Pandangan ini bersandar pada gejala-gejala yang menampakan diri, dimana peneliti berusaha memahami arti peristiwa dan kaitan-kaitannya dengan situasi tertentu dari perilaku seseorang atau sekelompok yang berhubungan dengan kecerdasan jamak dalam pembelajaran sentra. , Spradley memiliki model lebih rinci lagi dengan mengembangkan 12 tahap penelitian kualitatif tahapan tersebut dapat dilihat pada gambar berikut:

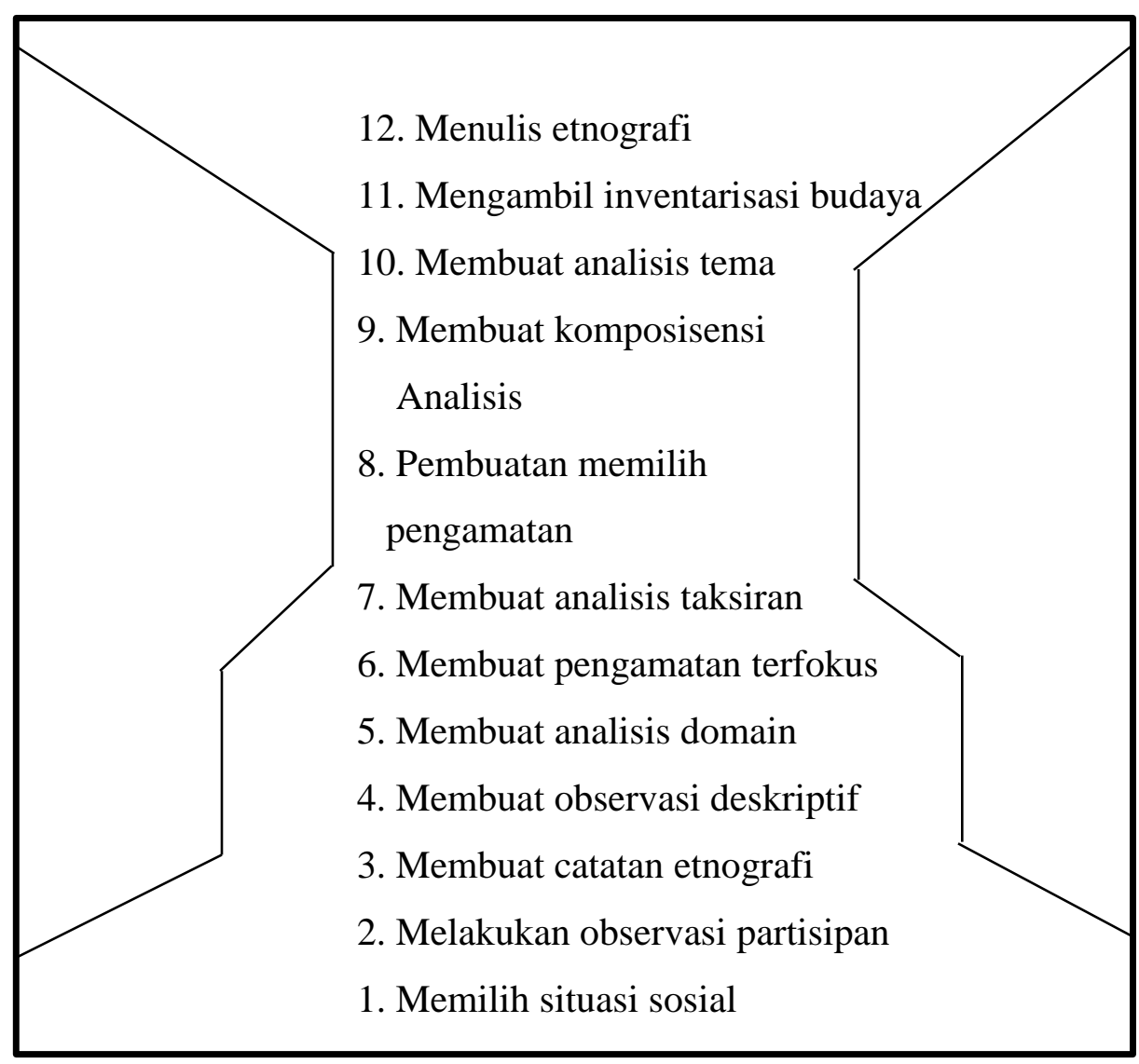

Gambar 1 (Tahapan Penelitian Spradley)

Adapun prosedur pengumpulan data berupa: (1) Pengamatan berperan serta, dilakukan setelah peneliti mendapat izin penggunaan lokasi penelitian dari 
pengelola dan kepala MI Asy Syukriyyah Tangerang. Dalam melakukan pengamatan, peneliti melibatkan diri secara langsung. Pengamatan peran serta secara terbuka diketahui oleh umum bahkan mungkin ia atau mereka disponsori oleh para subjek. Karena itu maka segala informasi termasuk rahasia sekalipun dapat dengan mudah diperolehnya. (2) Wawancara, adalah kegiatan percakapan dengan maksud tertentu. Kegiatan wawancara dilakukan bertahap sesuai kebutuhan penelitian dengan mengikuti jalur penelitian kualitatif yang telah ditetapkan.Pada penelitian ini wawancara terhadap informan menggunakan pedoman pertanyaan deskriptif dan pertanyaan terstruktur. (3) Pengumpulan dokumentasi, selain proses penelitian peneliti juga mengumpulkan dokumen. Dokumen ini bisa berupa dokumen publik (seperti koran, makalah, laporan kantor, ataupun dokumen private (seperti seilabus, rpp, atau program harian).

Catatan yang dibuat dilapangan sangat berbeda dengan catatan lapangan. Catatan itu berupa coretan seperlunya yang sangat dipersingkat, berisi kata-kata kunci, frasa, pokok-pokok sosiogram, diagram dan lain-lain. Pembuatan catatan lapangan dalam penelitian kualitatif sangatlah penting sebagai sebuah data empirik yang akan dianalisi, dan digunakan untuk menjawab pertanyaan permasalahan penelitian.

\section{HASIL PENELITIAN}

Temuan penelitian berdasarkan analisis domain sebagai berikut:

Tabel 1.

Analisis Domain

\begin{tabular}{|c|c|c|}
\hline Istilah bagian & Hubungan Sematik & Istilah Acuan (Kecerdasan) \\
\hline $\begin{array}{l}\text { Membaca do'a sebelum belajar } \\
\text { (CL1, CL2, CL3,... CL14) }\end{array}$ & Adalah Termasuk & Intrapersonal \\
\hline $\begin{array}{l}\text { Muroja'ah hafalan (CL1, CL2, } \\
\text { CL4, CL5, CL6, C17, CL8, } \\
\text { CL10, CL11, CL12, CL13, Cl14) }\end{array}$ & & \\
\hline $\begin{array}{l}\text { Membaca hadist (CL2, CL6, } \\
\text { CL9, CL13, CL14) }\end{array}$ & & \\
\hline $\begin{array}{l}\text { Menjadi Imam (CL1, CL2, } \\
\text { CL3,... CL14) }\end{array}$ & & \\
\hline $\begin{array}{l}\text { Membaca do'a niat wudhu, do'a } \\
\text { selesai wudhu dan masuk kamar } \\
\text { mandi (CL1, CL2, CL3,... CL14) }\end{array}$ & & \\
\hline $\begin{array}{l}\text { Wudhu sesuai aturan (CL1, CL2, } \\
\text { CL3,... CL14) }\end{array}$ & & \\
\hline $\begin{array}{l}\text { Shalat dhuha (CL1, CL2, CL3,... } \\
\text { CL14) }\end{array}$ & & \\
\hline
\end{tabular}


Membaca Asmaul Husna (CL1, CL2, CL4...CL14)

Membaca dzikir setelah shalat dhuha (CL1 CL2, CL3,... CL14)

Membaca sholawat (CL1, CL2, CL3,... CL14)

Berdo'a sebelum dan sesudah makan (CL1, CL2, CL3,... CL14)

Melakukan shalat dzuhur (CL1, CL2, CL3,... CL14)

Baca do'a keluar masuk kamar mandi (CL1, CL2, CL3,... CL14)

Membaca tahsin (CL1, CL2, CL4, CL6...CL14)

Menulis Arab saat tahsin (CL1, CL2, CL4, CL6, CL7...CL14)

Menambah hafalan (CL1, CL6, CL9)

Berdo'a ketika pulang (CL1, CL2, CL3,... CL14)

Kegiatan amal Jum'at (CL5, CL11, CL14)

Memakai seragam sesuai aturan (CL1, CL2, CL3,... CL14)

Wudhu sesuai aturan (CL1, CL2, CL3,... CL14)

Membentuk lingkaran dengan rapi (CL1, CL2, CL3,... CL14)

Berbaris rapi (CL1, CL2, CL3,... CL14)

Menggosok gigi (CL1, CL2, CL3,... CL14)

Menyampaikan kegiatan esok hari (CL1, CL2, CL3,... CL14)

Mengumpulkan tugas sesuai waktu (CL1, CL2, CL3,... CL14)

Meletakkan kembali peralatan yang telah digunakan (CL1, CL2, 
CL3,... CL14)

Makan sendiri (CL1, CL2,

CL3,... CL14)

Pergi ke toilet sendiri (CL1, CL2,

CL3,... CL14)

Memakai sepatu sendiri (CL1,

CL2, CL3,... CL14)

Mengerjakan tugas sendiri (CL1, CL2, CL3,... CL14)

Pergi study tour tanpa orangtua (CL3)

Mengerjakan tugas sesuai kemampuan (CL1, CL2, CL3,... CL14)

Mengerjakan tugas sampai tuntas (CL1, CL2, CL3,... CL14)

Pembelajaran akhlak tercela dan terpuji (CL6)

Mengambil dan meletakkan kembali barang pada tempatnya (CL1, CL2, CL3,... CL14)

Kegiatan beres-beres (CL1, CL2, CL3,... CL14)

Menghabiskan makanan (CL1, CL2, CL3,... CL14)

Meletakkan kembali peralatan makan (CL1, CL2, CL3,...

CL14)

Makan bergizi (CL1, CL2, CL3,... CL14)

Kegiatan pengenalan terhadap makhluk hidup dan benda mati (CL3)

Membuang sampah pada tempatnya (CL1, CL2, CL3,... CL14)

Mengklasifikan barang-barang sesuai cuaca (CL5)

Memberi konsekuensi jika telat Adalah Termasuk Interpersonal (CL2, CL5, CL7, CL9)

Datang tepat waktu (CL1, CL3, 
CL4, CL6, CL8, CL10...CL14)

Membuka kaos kaki dan

menggulung celana ketika

berwudhu (CL1, CL2, CL3,...

CL14)

Berbaris dengan rapi (CL1, CL2,

CL3,... CL14)

Meletakkan sepatu dan sandal di tempatnya (CL1, CL2, CL3,...

CL14)

Mengecek kehadiran (CL1, CL2,

CL3, CL4, CL9, CL10,

CL11,CL12, CL13, CL14)

Diberi izin untuk minum dan ke toilet sebelum pembelajaran

(CL5)

Diberi pijakan sebelum bermain

(CL2, CL4...CL14)

Menyampaikan kegiatan esok hari (CL1, CL2, CL3,... CL14)

Penyambutan anak(senyum, salam sapa) (CL1, CL2, CL6, CL7, CL9, CL10, CL12, CL14)

Mengucapkan salam (CL1, CL2, CL3...CL14)

Menanyakan kabar (CL1, CL2, CL3...CL14)

Sholawat sambil bersalaman (CL1, CL2, CL3,... CL14)

Saling memberi saat snack time (CL1, CL2, CL4, CL5, CL7, CL8, CL11, CL12, CL13, CL14)

Mengucapkan maaf dan terima kasih ketika pulang (CL1, CL2, CL3,... CL14)

Menolong teman yang membutuhkan (CL4)

Bekerja sama dengan baik ketika bermain dalam kelompok (CL2, CL4, CL6, CL9, CL10)

Bermain peran (CL2)

Bergantian menjadi pemimpin 


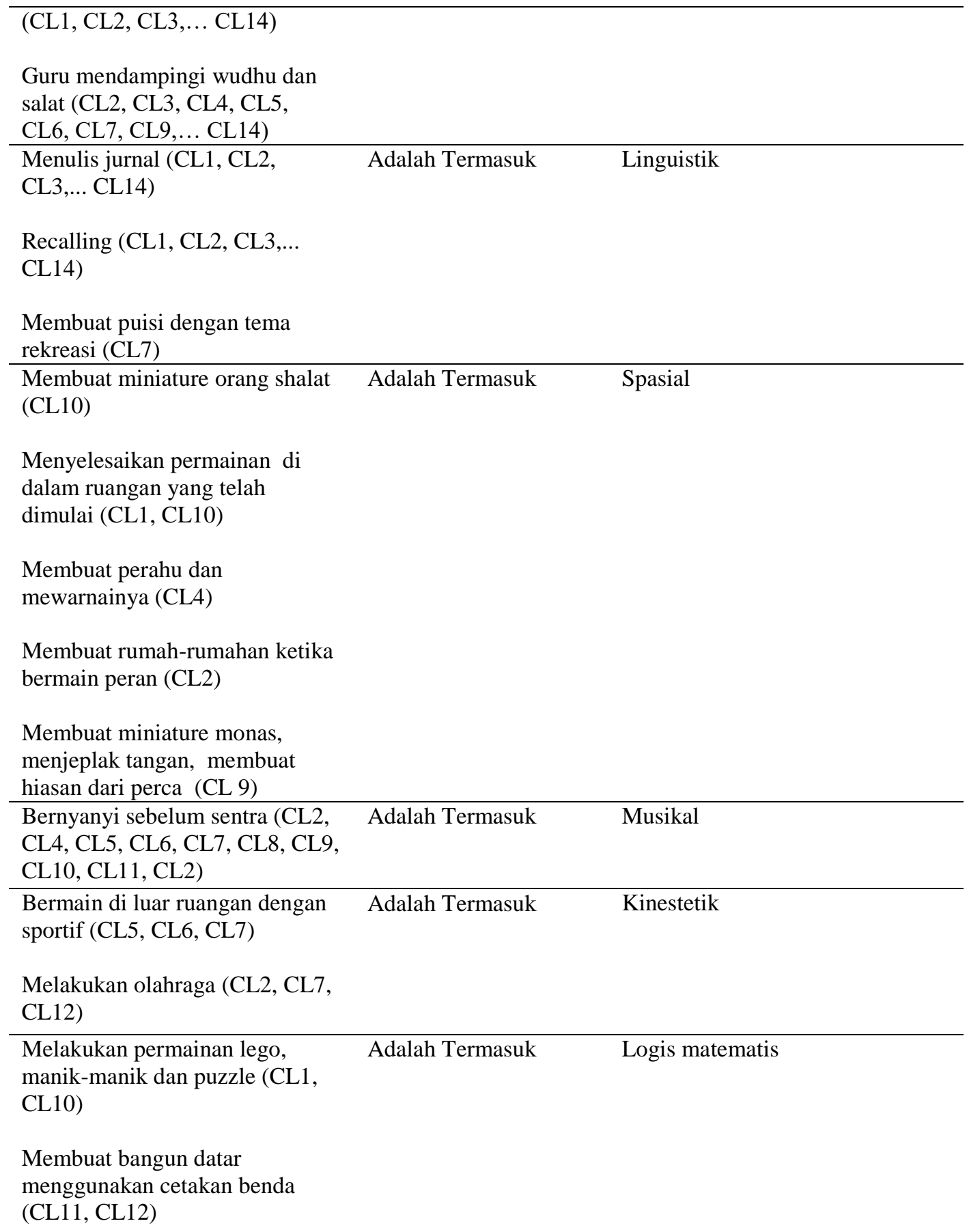

Hasil Analisis Taksonomi. Pembelajaran Sentra membangun delapan kecerdasan: Pertama Kecerdasan Intrapersonal dibangun melalui kegiatan a)Melaksanakan Ibadan wajib dan sunah. (sentra Imtaq); b)Berdoa sebelum dan sesudah beraktivitas (semuan sentra); c)Mempelajari quran-hadist (sentra imtaq); d)Mengerjakan tugas-tugas dengan mandiri (semua sentra); e)Disiplin terhadap peraturan (semua sentra); f)Bertanggung jawab pada tugas yang dikerjakan sampai tuntas (tidak meninggalkan jejak) (semua sentra). Kedua Kecerdasan Naturalis a)Mengenal makhluk hidup dan benda mati (sentra sains); b)Membuang 
sampah pada tempatnya (semua sentra); c)Mengklasifikasika benda sesuai cuaca (sains). Ketiga Kecerdasan Interpersonal a)Menerima konsekuensi jika melanggar peraturan (semua sentra); b)Bekerja sama dengan teman (Semua sentra); c)Menghormati guru (semua sentra); d)Menyayangi teman (Semua sentra); e)Berlatih menjadi pemimpin (semua sentra); f)Saling tolong menolong (semua sentra. Keempat Kecerdasan linguistik a)Kegiatan menulis jurnal (semua sentra); b)Membuat puisi (sentra bahasa); c)Kegiatan recalling (semua sentra). Kelima Kecerdasan spasial a)Membuat proyek dari barang bekas berupa miniature benda (sentra imtaq, dan seni); b)Membuat bangunan rumah-rumahan (sentra drama); c)Menggambar dan mewarnai (semua sentra). Keenam Musikal yaitu bernyanyi dan bertepuk tangan tangan sebelum pembelajaran (semua sentra). Ketujuh Kinestetik a)Permainan pembuka dalam ruangan luar ruangan (gobak sodor, tarik umbi, petak umpat, petak jongkok); b)Melakukan kegiatan olahraga (senam, bermain bola). Kedelapan Logis Matematis a)Permainan dalam ruangan (lego, manik-manik, dan puzzle); b)Mengenal dan membuat bangun datar sesuai ukuran ( setnra matematika); c)Transaksi jual beli (sentra drama)

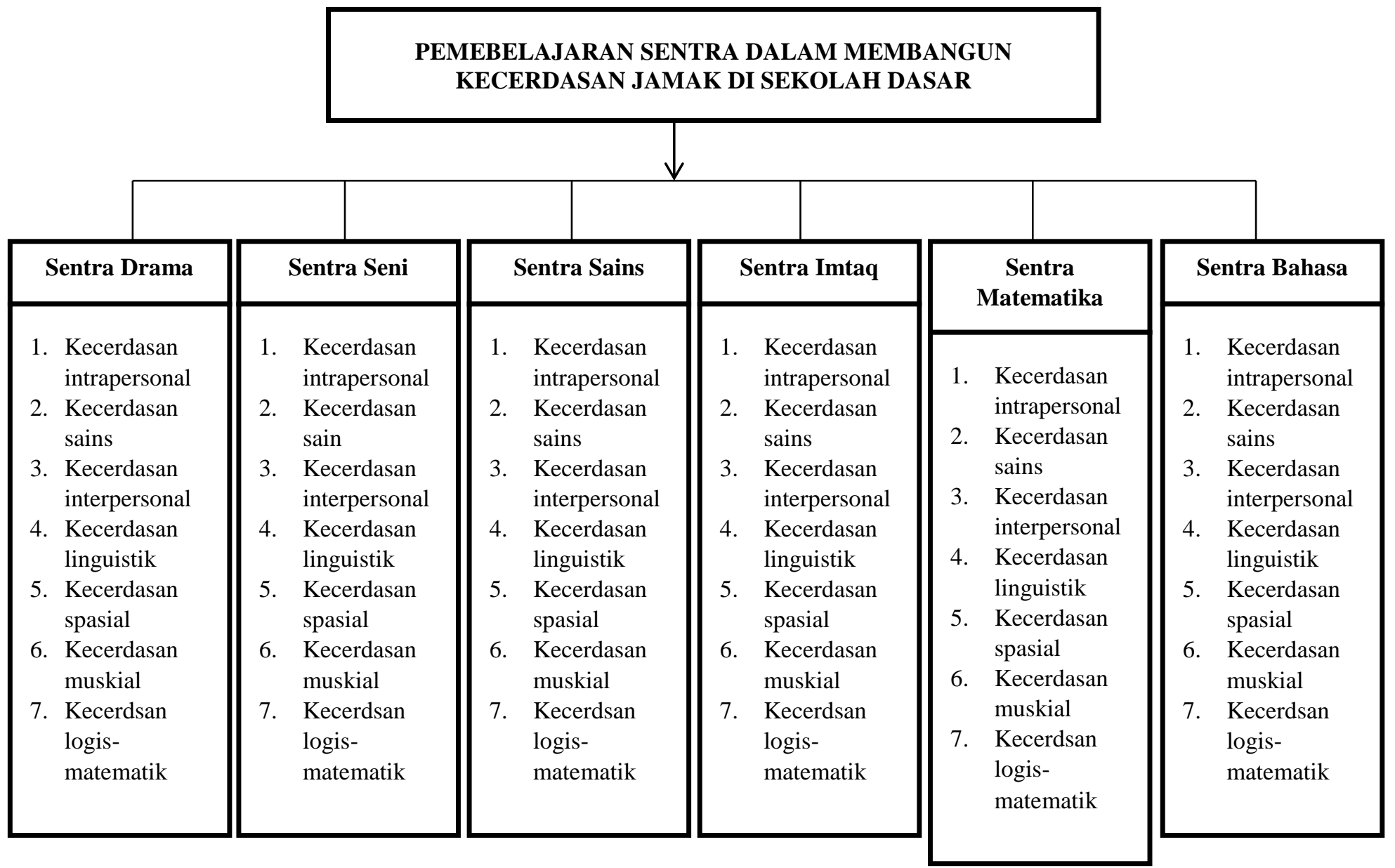

Gambar 1. Bagan Pembelajaran Sentra dalam Membangun Kecerdasan Jamak 


\section{PEMBAHASAN}

Dengan demikian dapat dilihat bahwa kegiatan-kegiatan sentra membangun kecerdasan jamak. Semua sentra membangun tujuh kecerdasan antara lain kecerdasan intrapersonal, kecerdasan naturalis, kecerdasan interpersonal, kecerdasan linguistik, kecerdasan spasial, kecerdasan musikal, dan kecerdasan logis-matematik adapun kecerdasan kinestetik dibangun melalui kegiatan diluar sentra yaitu kegiatan bermain bebas diluar kelas seperti bermain gobak sodor, tarik umbi, petak umpat dan petak jongkok. Kegiatan yang membangun kecerdasan kinestetik lainnya adalah kegiatan olahraga diluar kelas antara lain senam bersama dan bermain bola. Berikut dijelaskan kecerdasan-kecerdasan yang dibangun diseluruh sentra beserta kegiatannya:

Kecerdasan intrapersonal: melalui kegiatan berdoa sebelum dan sesudah, kedisiplinan anak terhadap peraturan, kemandirian anak menyelesaikan tugas dan tanggung jawab anak menuntaskan pekerjaannya. Kecerdasan interpersonal: karena pekerjaan anak disetiap sentra banyak dilakukan dalam kelompok kecil, dan memerlukan kerjasama dalam menggunakan alat dan bahan maka kecerdasan interpersonal dibangung disetiap sentra. anak juga dibiasakan menghormati guru dan menyayangi teman dengan cara berkata yang sopan dan baik, serta bertinggah laku yang tidak merugikan orang lain.

Kecerdasan naturalis: kecerdasan naturalis yang dibangun disetiap sentra berkaitan dengan mencintai lingkungan. Anak dapat membedakan sampah organik dan non organik dan membuangnya di tempat sampah yang telah disediakan. Kecerdasan Linguistik: kecerdasan ini juga dibangun di setiap sentra melalui kegiatan menulis jurnal rutin dipagi hari dan kegiatan recalling di akhir pembelajaran. Kecerdasan Spasial: kecerdasan dibangun disetiap sentr melalui kegiatan menggambar dan mewarnai. Karena semua sentra menggunakan pensil warna/crayon untuk menghias tugas yang dikerjakan.

Kecerdasan Musikal: kecerdasan musikan dibangun melalui kegiatan bernyanyi bersama setiap sebelum pembelajaran dimulai di setiap sentra.. Kecerdasan Logis-Matematis: kecerdasan ini dibangun disetiap sentra melalui kegiatan penggunaan alat ukur penggaris ketika membuat garis tepi. Adapun kecerdasan yang fokus dibangung disetiap sentra antara lain: Sentra Drama, fokus membangun kecerdasan linguistik melalui percakapan bermain drama, kecerdasan spasial melalui kegiatan membaut rumah-rumahan dari balok, kecerdasan logis-mat melalui kegiatan transaksi jual beli ketika bermain drama (penggunaan uang dan barang). Sentra Seni, fokus mengembangkan kecerdasan spasial melalui kegiatan menggambar dan mewarnaim dan membuat bangun datar/ruang membentuk miniature sebuah benda seperti perahu, bangunan monas, dan menghias bangun datar,

Sentra matematika, fokus membangun kecerdasan logis-mat melalui kegiatan mengenal bangun datar dan membuatnya menggunakan alat ukur penggaris. Sentra sains, fokus membangun kecerdasan naturalis melalui kegiatan 
mengenal dan mengklasifikasikan makhluk hidup dan benda mati, dan mengklasifikasikan benda yang dibutuhkan sesuai dengan cuaca. Sentra imtaq, fokus membangun kecerdasan intrapersonal melalui kegiatan yang berhubungan dengan Allah seperti kegiatan ibadah sunah dan wajib, mempelajari quran dan hadist, dan akhlak terpuji dan tercela.Kecerdasan spasial membuat miniature masjid dan orang sholat dari kardus bekas. Sentra bahasa, fokus mengembangkan kecerdasan linguistik melalui kegiatan menulis puisi indah.

\section{SIMPULAN}

Dari hasil dan pembahasan yang telah dijabarkan maka dapat disimpulkan bahwa pembelajaran sentra di MI Plus Asy-Syukriyyah membangun delapan kecerdasan jamak. Adapun kecerdasan yang dibangun antara lain kecerdasan: interpersonal, naturalis, intrapersonal, spasial, kinestetik, musical, linguistik dan logis matematik. Kecerdasan yang dibangun dibagi menjadi dua ada kecerdasan yang dibangun disetiap sentra, dan ada kecerdasan yang dibangun fokus dimasingmasing sentra. Dengan demikian kebutuhan anak dapat terpenuhi karena guru tidak hanya memperhatikan satu aspek kecerdasan saja. 


\section{DAFTAR PUSTAKA}

Chatib, M. (2013). Gurunya Manusia. Bandung: Mizan Pustaka

Depdiknas. (2006). Pendekatan Sentra dan Lingkaran dalam Pendidikan Anak UsiaDini. Jakarta: Depdiknas

Hoerr, T., R.. (2007). Buku Kerja Multiple Intelligences. Bandung: Mizan Pustaka

Jamaris, M. (2010). Orientasi Baru dalam Psikologi Pendidikan. Jakarta: Yayasan Penamas Murni

Mufrihatin. (2008). Aplikasi Metode BCCT (Beyond Centers and Circle Times) dalam Pembelajran Pendidikan Agaman Pada Anak Usia Dini. Yogyakarta: UIN Sunan Kalijaga

Mustaqim. (2004). Psikologi Pendidikan. Semarang: Fakultas Tarbiyah IAIN Walisongo

Power, B. (2005). Permainan Berbasis Sentra Pembelajaran. Jakarta: Erlangga

Puspitasari, M.,D. (2012). Implementasi Pembelajran Beyond Center and Circle Time di Kelompok Bermain (KB) Surya Ceria Aisyiyah (SCA) Karanganyar. Yogyakarta: NY

Spradley, J.,P. (1980). Participant Observation. USA: Holt, Rinehart and Witston 